\title{
SEX RATIO, LENGTH-WEIGHT RELATIONSHIPS AND MATURITY STAGES OF SALEMA (SARPA SALPA (LINNAEUS, 1758)) FROM THE CENTRAL ALGERIAN COAST (SOUTHWESTERN MEDITERRANEAN SEA)
}

\author{
AissAT-ZIAMNI, F. ${ }^{1,2^{*}}-$ GuEdIOURA, A. ${ }^{1,3}-$ NOUAR, A. ${ }^{1}$ \\ ${ }^{I}$ Fisheries Laboratory, Faculty of Biological Sciences, University of Sciences and Technology \\ Houari Boumediene, PB N³2 El Alia, Bab Ezzouar, 16111 Algiers, Algeria \\ ${ }^{2}$ Faculty of Sciences, Departement of Biology, University M'Hamed BOUGARA, Avenue of \\ independence, 35000 Boumerdes, Algeria \\ ${ }^{3}$ Faculty of Science of Nature and Life, University Saad Dahleb, BP 270, Blida 1 (09000), \\ Algeria \\ *Corresponding author \\ e-mail: aissat.faiza@yahoo.fr; phone: +213-553-773-819 \\ (Received $29^{\text {th }}$ Feb 2020; accepted $2^{\text {nd }}$ Jul 2020)
}

\begin{abstract}
The reproductive biology of Salema (Sarpa salpa (Linnaeus, 1758)) was investigated along the central Algerian coast (Southwestern Mediterranean Sea) from January to December 2015. A total of 712 individuals were collected and analysed from artisanal fisheries. The length frequency distribution indicated that males were frequent in the smaller size classes from 13.4 to $32.4 \mathrm{~cm}$, while the females in the larger size classes from 24.5 to $48.8 \mathrm{~cm}$. Characterized a protandrous and hermaphrodite species, the sex changes between 17.9 and $36 \mathrm{~cm}$ TL. The highest weights recorded were 446.18 and $1170.6 \mathrm{~g}$ for males and females, respectively. The sex ratio (females: males) of the whole sample showed a homogeneous distribution for both sexes. The length-weight relationships indicated an isometric growth of Sarpa salpa. The length at $50 \%$ maturity was $21.31 \mathrm{~cm}$ and $33.15 \mathrm{~cm}$ for males and females, respectively. Mature males were found between 16.5 and $29.5 \mathrm{~cm}$ and females in length classes of 29.5 and $40.5 \mathrm{~cm}$. Gonadosomatic index clearly indicated two spawning periods (spring and autumn) for both sexes.
\end{abstract}

Keywords: Sarpa salpa, sex distribution, reproductive indices, spawning period, Algeria

\section{Introduction}

The sparid Sarpa salpa (Linnaeus, 1758), commonly called Salema, is a benthopelagic gregarious fish, found upwards of 70 meters, from shallow waters, near algae or seagrass covered rocks, such as Posidonia oceanica and Cymodocea nodosa, as well as sandy bottoms (Harmelin-Vivien et al., 1995; Francour, 1997; Guidetti, 2000). This species is the main herbivorous demersal fish of the west Mediterranean Sea (Verlaque, 1990). It feeds on algae, diatoms and macrophytes (Havelange et al., 1997).

The Sarpa salpa is widely distributed along the European and African coasts (Eastern Atlantic), from the Bay of Biscay to South Africa (Bauchot and Hureau, 1986; Walt and Mann, 1998). In addition, it is present around Madeira, the Canary Islands, and Cape Verde (Bauchot and Hureau, 1986; Paiva et al., 2016). Sarpa salpa is also widely distributed throughout the Mediterranean Sea including Western, central and Eastern regions, and in the Black Sea (Bauchot and Hureau, 1986; Jadot et al., 2006; Pashkov and Reshetnikov, 2012). On the other hand, this species also been recorded in the Western Indian Ocean along the South African coast (Walt and Mann, 1998). 
Much information on several aspects of this species was reported; mainly on food and feeding habits (Christensen, 1978; Anato and Ktari, 1983a; Verlaque, 1985, 1990; Antolic et al., 1994; Havelange et al., 1997). In the Atlantic waters, studies were conducted on age and growth near the Canary Islands (Mendez-Villamil et al., 2001) and in the eastern waters of South Africa (Walt and Beckley, 1997) while age, growth, and reproduction of Salema have been reported on Portuguese coasts (Paiva et al., 2016).

In the Mediterranean Sea, growth, bimometric relationships, some aspects on the maturity and the reproductive biology of Sarpa salpa has been described (Sellami and Bruslé, 1975; Anato and Ktari, 1983b; Criscoli et al., 2006; Pallaoro et al., 2008; Acarli et al., 2014; Bayhan and Kara, 2015; El-Etreby et al., 2015). Recently, a study was conducted on Sarpa salpa in eastern Algeria (Groud and Kara, 2019) on sex ratio, growth and mortality, but no study on the reproductive biology has been mentioned so far on this species in Algeria. However, Sarpa salpa is known to be as a protandrous hermaphrodite (Mendez-Villamil et al., 2002; Paiva et al., 2014; Groud and Kara, 2019).

In Algeria, Sarpa salpa represents a potential source for local fishermen. Due to the lack of biological information on this species on the Algerian central coast, scientists are particularly interested in improving the regulation of its fisheries and proposing rational management measures for this species.

The purpose of this work is to acquire knowledge on the biology of reproduction of the Sarpa salpa by evaluating, for the first time on the central Algerian coast, its distribution of length and weight, sex ratio, length-weight relationships, maturity stages and the reproductive indices to ensure its sustainability.

\section{Materials and methods}

The specimens of Sarpa salpa were caught from artisanal fisheries using the trammel nets and the cast nets in the central region of Algeria, mainly at different ports of Cap Djinet, Zemmouri, Ain Taya, Bou Ismail and Cherchell (Fig. 1) from January to December 2015. A total of 712 individuals were analysed immediately in the laboratory.

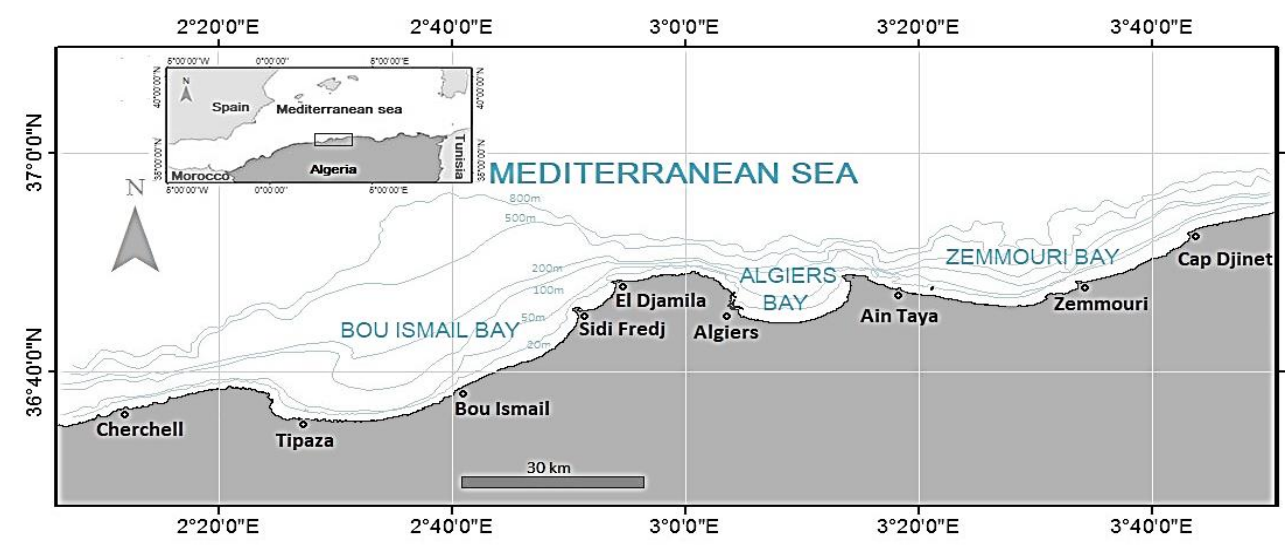

Figure 1. Location of the study area between Cherchell and Cap Djinet

For each specimen, the parameter of total length (TL) was taken accuracy $0.1 \mathrm{~cm}$. The total weight (TW) and gonad weight $(\mathrm{Wg})$ were recorded accuracy $0.01 \mathrm{~g}$. Sex 
(males, females, hermaphrodites and undetermined) and maturity stages were analysed macroscopically according to the maturity scale for partial spawners to classify the maturation stage (Holden and Raitt, 1974) (Table 1). It was difficult to distinguish stages I and II; this is why they were grouped and considered as the immature stage.

Table 1. Maturity scale for partial spawners (Holden and Raitt, 1974)

\begin{tabular}{|c|c|c|}
\hline Stage & State & Description \\
\hline I & Immature & $\begin{array}{l}\text { Ovary and testis about } 1 / 3 \text { rd length of body cavity. Ovaries pinkish, translucent; } \\
\text { testis whitish. Eggs not visible to naked eye. }\end{array}$ \\
\hline II & $\begin{array}{l}\text { Maturing virgin and } \\
\text { recovering spent }\end{array}$ & $\begin{array}{l}\text { Ovary and testis about } 1 / 2 \text { length of body cavity. Ovary pinkish, translucent; testis } \\
\text { whitish, more or less symmetrical. Eggs not visible to naked eye. }\end{array}$ \\
\hline III & Ripening & $\begin{array}{l}\text { Ovary and testis are about } 2 / 3 \text { rds length of body cavity. Ovary pinkish-yellow color } \\
\text { with granular appearance, testis whitish to creamy. No transparent or translucent } \\
\text { eggs visible. }\end{array}$ \\
\hline IV & Ripe & $\begin{array}{l}\text { Ovary and testis from } 2 / 3 \text { rds to full length of body cavity. Ovary orange-pink in } \\
\text { color with conspicuous superficial blood vessels. Large transparent, ripe eggs } \\
\text { visible. Testis whitish- creamy, soft. }\end{array}$ \\
\hline V & Spent & $\begin{array}{c}\text { Ovary and testis shrunken to about } 1 / 2 \text { length of body cavity. Walls loose. Ovary } \\
\text { may contain remnants of disintegrating opaque and ripe eggs, darkened or } \\
\text { translucent. Testis bloodshot and flabby. }\end{array}$ \\
\hline
\end{tabular}

The gonads for each sex, at different stages of maturity, were fixed in 5\% formaldehyde and subsequently were performed using standard histological techniques. Sections were cut at $3 \mu \mathrm{m}$ thickness and stained with Masson's trichrome.

Length-weight relationships were calculated for males and females and for the whole sample using the equation:

$$
\mathrm{TW}=\mathrm{a} \mathrm{TL}^{\mathrm{b}}
$$

The isometric hypothesis growth $(\mathrm{b}=3)$ was tested using the student's $t$-test. The slopes were tested to verify significant differences between sexes by analysis of covariance (ANCOVA). The analysis of one-way ANOVA was used to verify the possible difference in the total length between males, females and hermaphrodites, performed by the Tukey's test. The sex ratio (females: males) was calculated monthly considering length and season. Significant differences in the ratio of 1:1 were tested by the Chi-square $\left(\chi^{2}\right)$.

The total length at which $50 \%$ of the fish were sexual mature (TL $\left.\mathrm{T}_{50 \%}\right)$ was estimated for males and females during the spawning period (spring and autumn) using the following logistic function (Ghorbel et al., 1996):

$$
\mathrm{p}=\frac{1}{1+\mathrm{e}^{-(\mathrm{a}+\mathrm{bTL})}}
$$

where $\mathrm{P}$ was the percentage of mature individuals in the length class. $\mathrm{a}$ and $\mathrm{b}$ are constants:

$$
\text { TL50\% }=-\frac{a}{b}
$$


Parameters $a$ and $b$ were determined using least squares regression (Dagnelie, 1973), after converting the data into a logarithmic expression:

$$
\operatorname{Ln}(\mathrm{TW})=\operatorname{Ln}(\mathrm{a})+\mathrm{b} * \operatorname{Ln}(\mathrm{TL})
$$

The monthly evolution of the gonadosomatic index (GSI) (Bougis, 1952) was calculated in order to locate the spawning period. For both sexes, only specimens having reached the size of maturity were considered in the calculation (GSI):

$$
\mathrm{GSI}=\frac{\mathrm{Wg}}{\mathrm{TW}} * 100
$$

\section{Results}

\section{Length and Weight frequency distribution}

Of the 712 specimens analysed, 197 (27.69\%) were males, 175 (24.58\%) were females, 294 (41.29\%) were hermaphrodites and only $46(6.46 \%)$ were undetermined (Fig. 2).

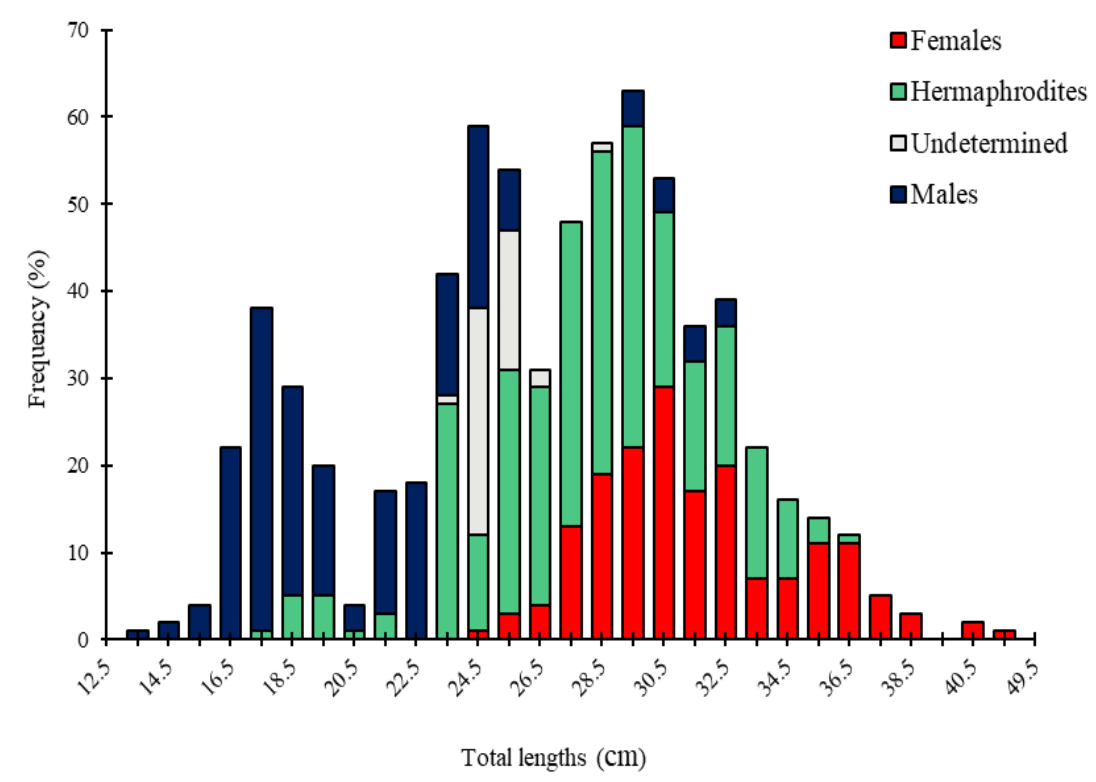

Figure 2. Length frequency distribution for males, females, hermaphrodites and undetermined from the central Algerian coast

The length frequency distribution indicated that males were frequent in the smaller size classes from 13.4 to $32.4 \mathrm{~cm}$ with an average of $20.81 \pm 4.15 \mathrm{~cm}$, while the females in the larger size classes from 24.5 to $48.8 \mathrm{~cm}$ with an average of $31.51 \pm 3.45 \mathrm{~cm}$. The size range of hermaphrodites individuals extended from 17.9 and $36 \mathrm{~cm}$ TL with an average of $27.99 \pm 3.55 \mathrm{~cm}$. The highest weights recorded were 446.18 and $1170.6 \mathrm{~g}$ for males and females, respectively. For all sexes, the means, maximum, minimum and standard deviations for total length and total weight were presented in Table 2. 
Table 2. Minimum, maximum, means, and standard deviations values of total length and total weight for females, males, hermaphrodites and undetermined from the central Algerian coast

\begin{tabular}{c|ccc|ccccc|c}
\hline & \multicolumn{4}{|c|}{ Length (cm) } & \multicolumn{4}{c|}{ Weight (g) } & $\begin{array}{c}\text { Post-hoc } \\
\text { test }\end{array}$ \\
\cline { 2 - 9 } & \multicolumn{2}{|c|}{ Minimum } & Maximum Mean ( \pm SD) & Minimum & Maximum & Mean $( \pm$ SD) & Number & S \\
\hline Females & 24.5 & 48.8 & $31.51 \pm 3.45$ & 213.35 & 1170.6 & $440.75 \pm 169.26$ & 175 & $* * *$ \\
Males & 13.4 & 32.4 & $20.81 \pm 4.15$ & 35.44 & 446.18 & $139.90 \pm 91.14$ & 197 & $* * *$ \\
Hermaphrodites & 17.9 & 36 & $27.99 \pm 3.55$ & 76.38 & 685.78 & $321.08 \pm 122.91$ & 294 & $* * *$ \\
Undetermined & 23 & 28 & $24.83 \pm 0.84$ & 173.18 & 344.21 & $211.27 \pm 29.19$ & 46 & $* * *$ \\
\hline
\end{tabular}

S: significant level $(* \mathrm{p}<0.05 ; * * \mathrm{p}<0.01 ; * * * \mathrm{p}<0.001 ;$ ns: not significant $)$

The ANOVA test showed that the difference in the total length was highly significant between males, females and hermaphrodites $(\mathrm{F}=411.67, \mathrm{P}<0.001)$. The post-hoc analysis performed by Tukey's multiple comparisons showed that these sizes were highly different $(\mathrm{P}<0.001)$.

\section{Sex ratio}

The sex ratio (females : males) of the whole sample showed a homogeneous distribution for both sexes. During all seasons, the sex ratio showed a significant difference between males and females $(\mathrm{p}<0.05)$ with a clear dominance of females in winter and spring, contrariwise males dominated in summer and autumn. However, the monthly distribution of sexes showed that the sex ratio was homogeneous at several months. Furthermore, no sex was observed in January; while in October no female was registered (Table 3).

Table 3. Sex ratio by season, month and total sample from central Algerian coast

\begin{tabular}{c|c|c|c|c|c|c|c|c}
\hline Seasons/Months & $\mathbf{N f}$ & $\mathbf{N m}$ & $\mathbf{N t o t}$ & $\mathbf{\%}$ Females & \% Males & Sex ratio & $\chi^{2}$ & S \\
\hline Winter & 19 & 8 & 27 & 70.37 & 29.63 & 2.38 & 4.48 & $*$ \\
Spring & 115 & 75 & 190 & 60.53 & 39.47 & 1.53 & 8.42 & $* *$ \\
Summer & 19 & 74 & 93 & 20.43 & 79.57 & 0.26 & 32.53 & $* * *$ \\
Autumn & 22 & 40 & 62 & 35.48 & 64.52 & 0.55 & 5.22 & $*$ \\
\hline January & - & - & - & - & - & - & - & - \\
February & 7 & 7 & 14 & 50 & 50 & 1 & - & $\mathrm{ns}$ \\
March & 79 & 56 & 135 & 58.52 & 41.48 & 1.41 & 3.92 & $*$ \\
April & 27 & 10 & 37 & 72.97 & 27.03 & 2.70 & 7.81 & $* *$ \\
May & 9 & 9 & 18 & 50 & 50 & 1 & 0 & $\mathrm{~ns}$ \\
June & 6 & 4 & 10 & 60 & 40 & 1.50 & 0.4 & $\mathrm{~ns}$ \\
July & 11 & 28 & 39 & 28.21 & 71.79 & 0.39 & 7.41 & $* *$ \\
August & 2 & 42 & 44 & 4.55 & 95.45 & 0.05 & 36.36 & $* * *$ \\
September & 6 & 6 & 12 & 50 & 50 & 1 & - & $\mathrm{ns}$ \\
October & - & 26 & 26 & - & 100 & - & - & - \\
November & 16 & 8 & 24 & 66.67 & 33.33 & 2 & 2.67 & $\mathrm{~ns}$ \\
December & 12 & 1 & 13 & 92.31 & 7.69 & 12 & 9.30 & $* *$ \\
\hline Total sample & $\mathbf{1 7 5}$ & $\mathbf{1 9 7}$ & $\mathbf{3 7 2}$ & $\mathbf{4 7 . 0 4}$ & $\mathbf{5 2 . 9 6}$ & $\mathbf{0 . 8 9}$ & $\mathbf{1 . 3 0}$ & $\mathbf{n s}$ \\
\hline
\end{tabular}

Nf: number of females, Nm: number of males, Ntot: total number of individuals, $\chi 2$ : chi square test, $\mathrm{S}$ : significant level $\left({ }^{*} \mathrm{p}<0.05 ; * * \mathrm{p}<0.01 ; * * * \mathrm{p}<0.001 ;\right.$ ns: not significant $)$ 
In the length range where the two sexes overlap $(24-33 \mathrm{~cm})$, the sex ratio showed a significant difference $(\mathrm{p}<0.05)$. As well at the length classes $(25-26 \mathrm{~cm})$, the sex ratio showed a homogeneous distribution of both sexes. Otherwise, the females were largely dominant at lengths range $(29-33 \mathrm{~cm})$ while males dominated at the size class $(24-25$ $\mathrm{cm})$. However, no male was observed in the length range $(26-29 \mathrm{~cm})$ and beyond the size class (33-34 cm) (Table 4).

Table 4. Sex ratio by length from the central Algerian coast

\begin{tabular}{|c|c|c|c|c|c|c|c|}
\hline Length class & $\mathbf{N m}$ & Male frequency \% & Nf & Female frequency $\%$ & Sex ratio & $\chi^{2}$ & $\mathbf{S}$ \\
\hline $13-14$ & 1 & 100 & & & & & \\
\hline $14-15$ & 2 & 100 & & & & & \\
\hline $15-16$ & 4 & 100 & & & & & \\
\hline $16-17$ & 22 & 100 & & & & & \\
\hline $17-18$ & 37 & 100 & & & & & \\
\hline $18-19$ & 24 & 100 & & & & & \\
\hline $19-20$ & 15 & 100 & & & & & \\
\hline $20-21$ & 3 & 100 & & & & & \\
\hline $21-22$ & 14 & 100 & & & & & \\
\hline $22-23$ & 18 & 100 & & & & & \\
\hline $23-24$ & 14 & 100 & & & & & \\
\hline $24-25$ & 21 & 95.45 & 1 & 04.55 & 0.05 & 18.18 & $* * *$ \\
\hline $25-26$ & 7 & 70 & 3 & 30 & 0.43 & 1.60 & $\mathrm{~ns}$ \\
\hline $26-27$ & & & 4 & 100 & & & \\
\hline $27-28$ & & & 13 & 100 & & & \\
\hline $28-29$ & & & 19 & 100 & & & \\
\hline $29-30$ & 4 & 15.38 & 22 & 84.62 & 5.50 & 12.46 & $* * *$ \\
\hline $30-31$ & 4 & 12.12 & 29 & 87.88 & 7.25 & 18.94 & $* * *$ \\
\hline $31-32$ & 4 & 19.05 & 17 & 80.95 & 4.25 & 8.05 & $* *$ \\
\hline $32-33$ & 3 & 13.04 & 20 & 86.96 & 6.67 & 12.56 & $* * *$ \\
\hline $33-34$ & & & 7 & 100 & & & \\
\hline $34-35$ & & & 7 & 100 & & & \\
\hline $35-36$ & & & 11 & 100 & & & \\
\hline $36-37$ & & & 11 & 100 & & & \\
\hline $37-38$ & & & 5 & 100 & & & \\
\hline $38-39$ & & & 3 & 100 & & & \\
\hline $39-40$ & & & & & & & \\
\hline $40-41$ & & & 2 & 100 & & & \\
\hline$>41$ & & & 1 & 100 & & & \\
\hline
\end{tabular}

$\mathrm{Nm}$ : number of males, Nf: number of females, $\chi 2$ : chi square test, S: significant level $(* \mathrm{p}<0.05$;

$* * \mathrm{p}<0.01 ; * * * \mathrm{p}<0.001 ; \mathrm{ns}$ : not significant)

\section{Length-weight relationships}

The length-weight relationships were studied for the overall sample; either for males, females and hermaphrodite sexes separately (Table 5). The student's $t$-test showed that the value of the slope (b) of the length-weight relationships was not statistically different from 3, which indicated an isometric growth of Sarpa salpa.

Furthermore, the slopes comparison (ANCOVA test) between males and females showed a high difference in the length-weight relationship $(\mathrm{F}=1.383, \mathrm{P}<0.001)$. The same result was obtained $(\mathrm{P}<0.001)$ when slopes where compared between hermaphrodite - males and hermaphrodite - females, respectively. 
Table 5. Parameters of length-weight relationships for males, females, hermaphrodites and total sample

\begin{tabular}{c|c|c|c|c}
\hline Sex & $\mathbf{a}$ & $\mathbf{b}$ & $\mathbf{R}^{\mathbf{2}}$ & $\mathbf{S}$ \\
\hline Males & 0.0163 & 2.947 & 0.98 & $\mathrm{~ns}$ \\
Females & 0.0117 & 3.042 & 0.87 & $\mathrm{~ns}$ \\
Hermaphrodites & 0.0117 & 3.05 & 0.95 & $\mathrm{~ns}$ \\
Total & 0.015 & 2.973 & 0.98 & $\mathrm{~ns}$ \\
\hline
\end{tabular}

$\mathrm{R}^{2}$ : determination coefficient, a and b: parameters, $\mathrm{S}$ : statistical significance of $\mathrm{b}$ compared to isometry at 3 (ns: not significant)

\section{Length at first sexual maturity}

The total length at $50 \%$ sexual maturity (TL50\%) was $21.31 \mathrm{~cm}$ and $33.15 \mathrm{~cm}$ for males and females, respectively (Fig. 3).

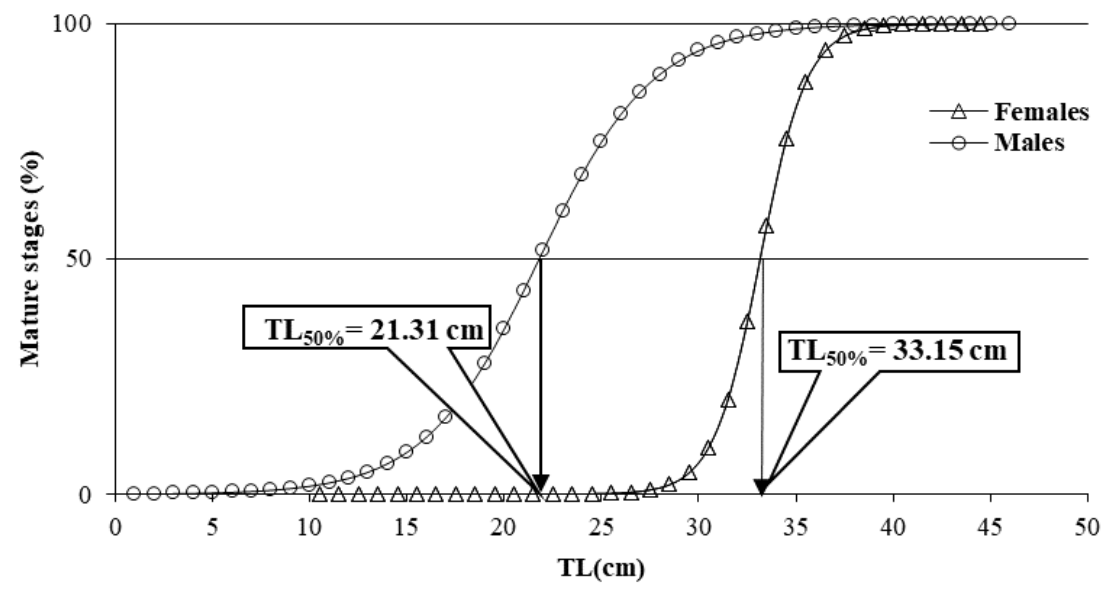

Figure 3. Sigmoid curves with percentage of sexually mature individuals by length indicating $T L_{50 \%}$ for males and females from the central Algerian coast

The smallest mature male individual was found in the 16-17 $\mathrm{cm}$ length interval and measured $16.5 \mathrm{~cm}$ with $61.53 \mathrm{~g}$ for total weight. For females, the first mature individual was observed in 29-30 cm length interval with $29.5 \mathrm{~cm}$ of length and $371.06 \mathrm{~g}$ for total weight (Table 6).

\section{Maturity stages and reproductive indices}

In the whole sample, $28 \%$ of females and $16.25 \%$ of males were mature. The mature males were found between 16.5 and $29.5 \mathrm{~cm}$, and females 29.5 and $40.5 \mathrm{~cm}$ (except for a female $48.5 \mathrm{~cm}$ ) (Table 6). For both sexes, mature individuals appear from March to July and from September to November. However, in February, August and September all males and females were immature. GSI showed two highest spawning periods values in females (1.28 and 2.05) than in males ( 0.76 and 0.5$)$ at spring and autumn, respectively. Throughout the year, the stage of maturity (IV) was not observed for both sexes (Fig. 4A,B).

The inversion of sex occurs between 17.5 and $36.5 \mathrm{~cm}$ total length and the examination of hermaphrodite gonads revealed that the juvenile gonad consists on an ovotestis in which, the tissues of males and females were completely separated with a clear domination of the male part (Fig. 5). 
Table 6. Number $(N)$ and percentage (\%) of maturity stages for males and females

\begin{tabular}{|c|c|c|c|c|c|c|c|c|}
\hline \multirow{3}{*}{$\frac{\text { Sexes }}{\text { Length }}$} & \multicolumn{4}{|c|}{ Males } & \multicolumn{4}{|c|}{ Females } \\
\hline & \multicolumn{2}{|c|}{ Immature } & \multicolumn{2}{|c|}{ Mature } & \multicolumn{2}{|c|}{ Immature } & \multicolumn{2}{|c|}{ Mature } \\
\hline & $\mathbf{N}$ & $\%$ & $\mathbf{N}$ & $\%$ & $\mathbf{N}$ & $\%$ & $\mathbf{N}$ & $\%$ \\
\hline 13-14 & 1 & 0.51 & & & & & & \\
\hline $14-15$ & 2 & 1.02 & & & & & & \\
\hline $15-16$ & 4 & 2.03 & & & & & & \\
\hline $16-17$ & 19 & 86.36 & 3 & 13.64 & & & & \\
\hline $17-18$ & 35 & 94.59 & 2 & 5.41 & & & & \\
\hline $18-19$ & 23 & 95.83 & 1 & 4.17 & & & & \\
\hline $19-20$ & 9 & 60.00 & 6 & 40 & & & & \\
\hline $20-21$ & 3 & 60.00 & 2 & 40 & & & & \\
\hline $21-22$ & 12 & 85.71 & 2 & 14.29 & & & & \\
\hline $22-23$ & 16 & 94.12 & 1 & 5.88 & & & & \\
\hline $23-24$ & 13 & 76.47 & 4 & 23.53 & & & & \\
\hline $24-25$ & 17 & 85 & 3 & 15 & 1 & 100 & & \\
\hline $25-26$ & 4 & 66.67 & 2 & 33.33 & 3 & 100 & & \\
\hline $29-30$ & 2 & 66.67 & 1 & 33.33 & 4 & 80 & 1 & 20 \\
\hline $30-31$ & 3 & 42.86 & 4 & 57.14 & 13 & 92.86 & 1 & 7.14 \\
\hline $32-33$ & 2 & 66.67 & 1 & 33.33 & 19 & 82.61 & 4 & 17.39 \\
\hline $33-34$ & & & & & 21 & 77.78 & 6 & 22.22 \\
\hline $34-35$ & & & & & 28 & 90.32 & 3 & 9.68 \\
\hline $35-36$ & & & & & 13 & 72.22 & 5 & 27.78 \\
\hline $36-37$ & & & & & 14 & 60.87 & 9 & 39.13 \\
\hline $37-38$ & & & & & 4 & 30.77 & 9 & 69.23 \\
\hline $38-39$ & & & & & 2 & 28.57 & 5 & 71.43 \\
\hline $39-40$ & & & & & 2 & 40 & 3 & 60 \\
\hline $40-41$ & & & & & 2 & 50 & 2 & 50 \\
\hline$>41$ & & & & & & & 1 & 100 \\
\hline Total & 165 & & 32 & $16.25 \%$ & 126 & & 49 & $28 \%$ \\
\hline
\end{tabular}
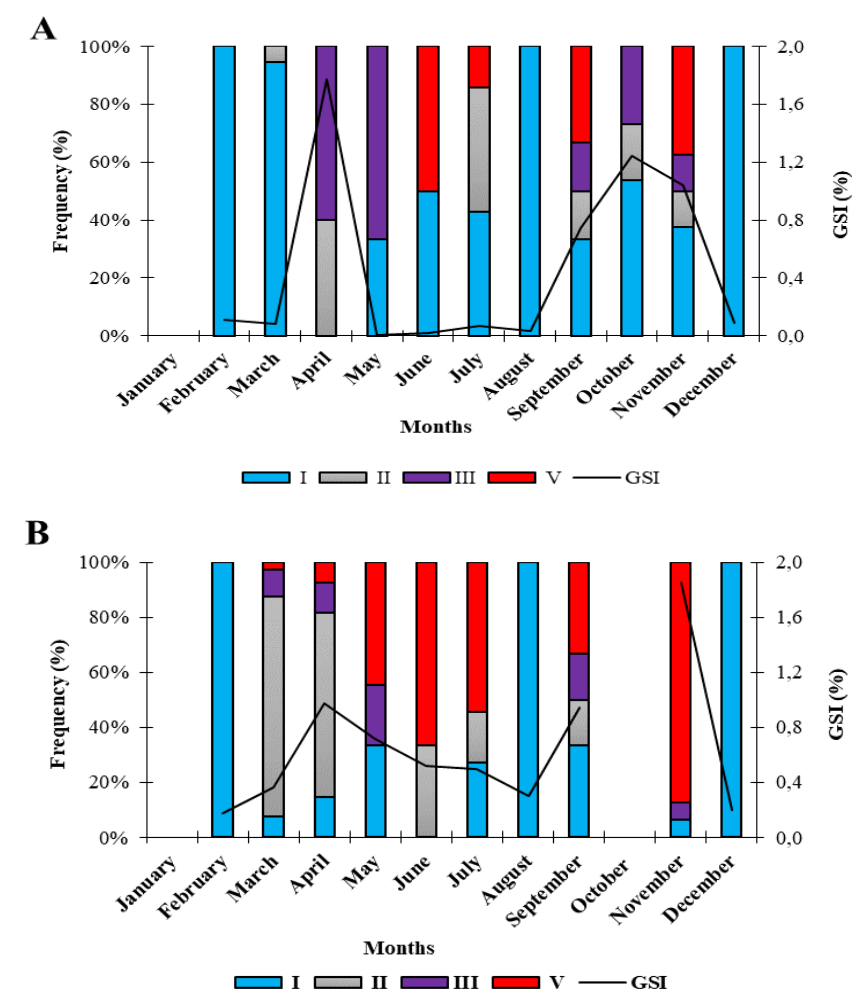

Figure 4. Monthly variation of the maturity phases and gonadosomatic index (GSI) for Sarpa salpa. Males (A) and females (B). I, immature; II, maturing; III, mature; v, spent 


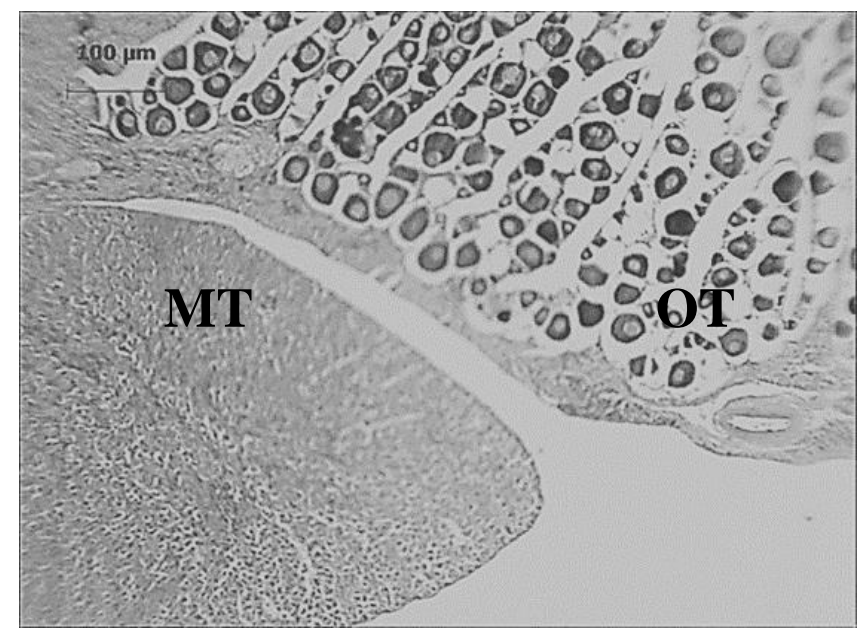

Figure 5. Cross-section of juvenile hermaphrodite gonad ( $T L=23.9 \mathrm{~cm}, W=179.59 \mathrm{~g}) . M T$, male tissue; OT, ovarian tissue

\section{Discussion}

The fishery management of hermaphrodite species, like most fish populations, requires knowledge of the lengths of the captured individuals and the specific reproductive pattern of each species. The length frequency distribution of Sarpa salpa indicated that males were frequent in the smaller length while the females in the larger length and the hermaphrodites size range was intermediate. This distinction in the average sizes of the three sexes in the sense of males, hermaphrodites and females, confirmed the gradual change of sex process and protandry of Salema. Lissia-Frau and Casu (1968), Walt and Mann (1998), Mendez-Villamil et al. (2002), Criscoli et al. (2006), Paiva et al. (2016) and Groud and Kara (2019) observed the same protandrous hermaphrodism of this species. In other sparid species, such as Pagellus bogaraveo and Pagellus acarne, the reproductive modalities are of the protandric type (Lechekhab et al., 2010; Boufersaoui and Harchouche, 2015), while they are protogynous in Boops boops (Amira et al., 2019). Indeed, Mellinger (2002), observed a wide variety of modalities of sexual change in Sparids.

In our work, the sex ratio (females: males) of the whole sample showed a homogeneous distribution for both sexes. By seasons, it showed a dominance of males in summer and autumn, unlike in winter and spring where the sex ratio was in favor of females that dominated large size classes. The differences in the sex ratio of males and females between the seasons could be explained by the differences in their behavior but the sex of the fish did not change.

However, the results obtained in the central-east Atlantic (Canarian Archipelago) (Mendez-Villamil et al., 2002) and along the eastern coast of Algeria (Groud and Kara, 2019) highlighted the dominance of male. Our findings are also in disagreement with those of Pollock (1985), claiming that the sex ratio of protandric sparids might be skewed towards males. Such differences in sex ratio with Sarpa salpa of the central Algerian coasts would be related to the selective fishing nets used for the landing of this species in the study area (the trammel nets and the cast nets).

Length-weight relationships revealed an isometric growth of Sarpa salpa, the value of the $b$ parameters for males, females, hermaphrodites and total sample were not significantly different from 3 . The same conclusion was reached by Mendez-Villamil et 
al. (2002) for the population of Canarian Archipelago and Criscoli et al. (2006) along the Italian Mediterranean coast.

Allometric growth was shown for females and an isometric growth for males (Pallaoro et al., 2008) while Matic'-Skoko et al. (2004) and Acarli et al. (2014) have observed a positive allometric growth in the Kornati Archipelago and in Izmir Bay (Turkey), respectively. These authors suggested that the difference of the length-weight relationship between males and females was probably due to the difference in length distribution of both sexes as a consequence of the sexual pattern. Additionally, Froese (2006) has reported that data from different areas, not obtained in the same season / year influence the length-weight relationship.

In the overall sample, $28 \%$ of females and $16.25 \%$ of males were mature. this small ratio of mature fish could be explained by the small number sampled during the two spawning periods (March-June and September-November), as well as the total absence of males in October.

Monthly evolution of percentages of maturity and high GSI values of males and females of Salema during the total period suggested that autumn and spring were the two periods of intense reproductive activity. In the same species, Corbera et al. (1998) and Criscoli et al. (2006) reported a similar spawning periods in the Western Mediterranean Sea. In addition, the breeding activity of this species is spread over a single period while heading east of the Mediterranean Sea. Indeed, Anato and Ktari (1983b), Pallaoro et al. (2008) and El-Etreby et al. (2015) reported a single period in autumn, while Mouneimne (1978) observed maximum breeding in winter. In the northeast Atlantic, this activity also appears to follow a gradient from Cape Verde to Portugal (Mendez-Villamil et al., 2002; Russell et al., 2014; Paiva et al., 2016). Nonetheless, Van der Waltand Mann (1998) observed that the period of the reproductive activity of Salema extended from March to September with peak of maturation from April to August in the east coast of South Africa. All these changes in the reproductive period may be the result of several factors. Wootton (1990) suggested that this difference was due to environmental factors and that temperature appears to be the most important one. Likewise, Sarkar and Upadhyay (2011) suggested that the changes were due to the biotic and environmental factors or the combination of both (Falcón et al., 2003).

In this study, length at first sexual maturity was $21.31 \mathrm{~cm}$ and $33.15 \mathrm{~cm}$ for males and

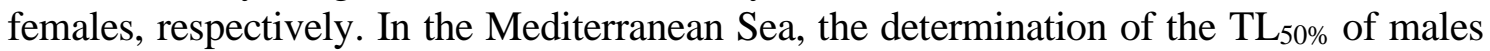
by different authors was all close to our result with $19.5 \mathrm{~cm}$ in central western coasts of Italy (Criscoli et al., 2006), $20.6 \mathrm{~cm}$ in the middle-eastern Adriatic (Pallaoro et al., 2008) and $21.1 \mathrm{~cm}$ in the Libyan coast (El-Etreby et al., 2015). In Atlantic waters, values of $\mathrm{TL}_{50 \%}$ for males were significantly higher and in the Portuguese waters $24.5 \mathrm{~cm}$ (Paiva et al., 2016) and Canarian Archipelago $26.6 \mathrm{~cm}$ (Mendez-Villamil et al., 2002).

In the Algerian coast, the smallest mature female observed was $29.9 \mathrm{~cm}$. Close values have been observed in the Atlantic. Indeed, Paiva et al. (2016) in the Portuguese waters and Mendez-Villamil et al. (2002) in Canarian Archipelago enregistred the smallest mature females with the respective values of $28.6 \mathrm{~cm}$ and $29.4 \mathrm{~cm}$.

\section{Conclusion}

This study provides knowledge on the sex ratio, length-weight relationships and maturity stages of Sarpa salpa (Linnaeus, 1758) from the Central Algerian coast. The length frequency distribution indicated that males were frequent in the smaller size 
classes, while the females in the larger size classes. Characterized a protandrous and hermaphrodite species, hermaphrodites appear between 17.9 and $36 \mathrm{~cm}$ TL. The sex ratio (females : males) of the whole sample showed a homogeneous distribution for both sexes. On the other hand, the length-weight relationship indicated an isometric growth of Sarpa salpa. The length at $50 \%$ maturity was $21.31 \mathrm{~cm}$ and $33.15 \mathrm{~cm}$ for males and females, respectively. The smallest mature male individual was found measured $16.5 \mathrm{~cm}$ with $61.53 \mathrm{~g}$ for total weight. For females, the first mature individual was observed with $29.5 \mathrm{~cm}$ of length and $371.06 \mathrm{~g}$ for total weight. Gonadosomatic index indicated two spawning periods (spring and autumn) for both sexes.

Future studies should attempt to determine the influence of the protandrous biology of Sarpa salpa at different age of its growth. It also very important to study the fecundity process for a better management of stocks in the Algerian coasts.

Acknowledgments. We would like to thanks to Mrs. AINOUCHE N and Mrs. LAMOUTI S, fishery researcher in the National Research Center for Development of aquaculture and fishery and Mrs KHEMILI A for their invaluable help in carrying out this work.

\section{REFERENCES}

[1] Acarli, D., Kara, A., Bayhan, B. (2014): Length-weight relations for 29 fish species from Homa Lagoon, Aegean Sea, Turkey. - Acta Ichthyologia Piscatoria 44(3): 249-257.

[2] Amira, S., Alioua, Z., Harchouche, K. (2019): Gonadal development and fecundity of bogue Boops boops (Linnaeus, 1758) (Sparidae) on the central Algerien coast. - Turkish Journal of Zoology 43: 12-29.

[3] Anato, C. B., Ktari, M. H. (1983a): Régime alimentaire de Boops boops (Linné,1758) et de Sarpa salpa (Linné, 1758), poissons téléostéens sparidés du golfe de Tunis. - Rapport des réunions de la Commission Internationale pour l'Exploitation Scientifique de la Mer Méditerranée 28: 33-34.

[4] Anato, C. B., Ktari, M. H. (1983b): Reproduction de Boops boops (Linné, 1758) et de Sarpa salpa (Linnaeus, 1758), Poissons Téléostéens, Sparidés du Golfe de Tunis. Bulletin de l'Institut National Scientifique et Technique d'Océanographie et de Pêche,Salammbô 10: 49-53.

[5] Antolic, B., Skaramuca, B., Span, A., Musin, D., Sanko-Njire, J. (1994): Food and feeding habits of a herbivore fish Sarpa salpa (L.) (Teleostei, Sparidae) in the southern Adriatic (Croatia). - Acta Adriatica 35: 45-52.

[6] Bauchot, M. L., Hureau, J. C. (1986): Sparidae. - In: Whitehead, P. J., Bauchot, M. L., Hurau, J. C., Nielsen, J., Tortonese, E. (eds.) Fishes of the North-eastern Atlantic and Mediterranean. Vol. 2, UNESCO, United Kingdom, pp. 883-907.

[7] Bayhan, B., Kara, A. (2015): Length-Weight and Length-Length Relationships of the Salema Sarpa salpa (Linnaeus, 1758) in Izmir Bay (Aegean Sea of Turkey). - Pakistan journal of Zoologie 47(4): 1141-1146.

[8] Boufersaoui, S., Harchouche, K. (2015): Dynamique de la reproduction et fécondité de Pagellus acarne (Sparidae) de la région Centre du littoral algérien. - Cybium 39(1): 5969.

[9] Bougis, P. (1952): Recherches biométriques sur les rougets (Mullus barbatus L., Mullus Surmuletus L.). - Archives de Zoologie Expérimentale et Générale 89: 57-174.

[10] Christensen, M. (1978): Trophic relationships in juveniles of three species of sparid fishes in the South African marine littoral. - Fishery Bulletin 76: 389-401.

[11] Corbera, J., Sabatés, A., Garcia-Rubies, A. (1998): Peces de Mar de la Péninsula iberica. - Editorial Planeta, Barcelona. 
[12] Criscoli, A., Colloca, F., Carpentieri, P., Belluscio, A., Ardizzone, G. (2006): Observations on the reproductive cycle, age and growth of the salema, Sarpa salpa (Osteichthyes: Sparidae) along the western central coast of Italy. - Scientia Marina 70: 131-138.

[13] Dagnelie, P. (1973): Théorie et méthodes statistiques. - Presses agronomiques de Gembloux, France.

[14] El-Etreby, S. G., Ahmed, A. I., Alwany, M. A., Ali, R. A. (2015): Reproductive biology of the Salema, fish Sarpa salpa (Osteichthyes: Sparidae) along the eastern coast of Libya. - Egyptian Journal of Aquatic Biology and Fisheries 19: 83-94.

[15] Falcón, J., Besseau, L., Fazzari, D., Attia, J., Gaildrat, P., Beauchau, M., Boeuf, G. (2003): Melatonin modulates secretion of growth hormone and prolactin by trout pituitary glands and cells in culture. - Endocrinology 144: 4648-4658.

[16] Francour, P. (1997): Fish assemblages of Posidonia oceanica beds at Port Cros (France, NW Mediterranean): assessment of composition and long-term fluctuations by visual census. - Marine Ecology 18(2): 157-173.

[17] Froese, R. (2006): Cube law, condition factor and weight-length relationships: history, meta-analysis and recommendations. - Journal of Applied Ichthyology 22: 241-25.

[18] Ghorbel, M., Jarboui, O., Bradai, M. N., Bouain, A. (1996): Détermination de la taille de première maturité sexuelle par une fonction logistique chez Limanda limanda, Pagellus erythrinus et Scorpaena porcus. - Bulletin de l'Institut National des Sciences Technologiques et de la Mer 3: 24-27.

[19] Groud, L. L., Kara, M. H. (2019): Sex-ratio, growth and mortality of the Salema Sarpa salpa (Linnaeus, 1758) (Teleostei: Sparidae) along the eastern coast of Algeria. - Cahier de Biologie Marine 60(3): 253-261.

[20] Guidetti, P. (2000): Differences among fish assemblages associated with nearshore Posidonia oceanica seagrass beds, rocky-algal reefs and unvegetated sand habitats in the Adriatic Sea. - Estuarine Coastal and Shelf Science 50: 515-529.

[21] Harmelin-Vivien, M. L., Harmelin, J. G., Leboulleux, V. (1995): Microhabitat requirements for settlement of juvenile sparid fishes on Mediterranean rocky shores. Hydrobiologia 301: 309-320.

[22] Havelange, S., Lepoint, G., Dauby, P., Bouquegneau, J. M. (1997): Feeding of the sparid fish Sarpa salpa in a seagrass ecosystem: diet and carbon flux. - Marine Ecology 18(4): 289-297.

[23] Holden, M. J., Raitt, D. F. S. (1974): Manual of fisheries science. Part 2: Methods of resource investigation and their application. - FAO Fisheries Technical Report., 115: Rev. 1 Rome, Italy.

[24] Jadot, C., Donnay, A., Acolas, M., Cornet, Y., Bégout-Anras, M. (2006): Activity patterns, home-range size, and habitat utilization of Sarpa salpa (Teleostei: Sparidae) in the Mediterranean Sea. - ICES Journal of Marine Science 63: 128-139.

[25] Lechekhab, S., Lechekhab, H., Djebar, B. (2010): Evolution des gonades hermaphrodites lors du cycle sexuel de Pagellus bogaraveo (Sparidae) dans le golfe d'Annaba, côtes Est d'Algérie. - Cybium 34(2): 167-174.

[26] Lissia-Frau, A. M., Casu, S. (1968): Il processo gonado genetico in alcune specie di Sparidi (Teleostei, Perciformes). - Studi Sassaresi 1: 1-23.

[27] Matic'-Skoko, S., Kraljevic', M., Dulc 'ic', J., Pallaoro, A. (2004): Growth of juvenile salema, Sarpa salpa (Teleostei: Sparidae), in the Kornati Archipelago, eastern Adriatic Sea. - Scientia Marina 68: 411-417.

[28] Mellinger, J. (2002): Sexualité et reproduction des Poissons. - CNRS Éditions, Paris.

[29] Mendez-Villamil, M., Pajuelo, J. G., Lorenzo, J. M., Coca, J., Ramos, A. (2001): Age and growth of the salema, Sarpa salpa (Osteichthyes, Sparidae) off the Canary Islands (Eastcentral Atlantic). - Archive of Fishery and Marine Research 49(2): 139-148. 
[30] Mendez-Villamil, M., Lorenzo, J. M., Pajuelo, J. G., Ramos, A., Coca, J. (2002): Aspects of the history of the salema, Sarpa salpa (Pisces, Sparidae), off the Canarian Archipelago (central-east Atlantic). - Environmental Biology of Fishes 63: 183-192.

[31] Mouneimne, N. (1978): Poissons des côtes du Liban. - Thèse de Doctorat d'Etat EsSciences Naturelles. Université Pierre et Marie Curie, Paris $6^{\text {ème }}$.

[32] Paiva, R. B., Neves, A., Vieira, A. R., Sequeira, V., Vendrell, C. (2014): Cystic structures in fish ovaries: more common than we think. The case study of Sarpa salpa (Sparidae). Cybium 38(2): 158-160.

[33] Paiva, R. B., Neves, A., Sequeira, V., Vieira, A. R., Costa, M. J., Gordo, L. (2016): Age, growth and reproduction of the protandrous hermaphrodite fish, Sarpa salpa, from the Portuguese continental coast. - Journal of the Marine Biological Association of the United Kingdom 98(2): 269-281.

[34] Pallaoro, A., Dulčić, J., Matić-Skoko, S., Kraljević, M., Jardas, I. (2008): Biology of the salema, Sarpa salpa (L. 1758) (Pisces, Sparidae) from the middle-eastern Adriatic. Journal of Applied Ichthyology 24: 276-28.

[35] Pashkov, A. N., Reshetnikov, S. I. (2012): First catch of salema Sarpa salpa (Perciformes, Sparidae) in waters of Russia. - Journal of Ichthyology 52: 566-568.

[36] Pollock, B. R. (1985): The reproductive cycle of yellowfin bream, Acanthopagms australis (Günther), with particular reference to protandrous sex inversion. - Journal of Fish Biology 26(3): 301-311.

[37] Russell, B., Pollard, D., Mann, B. Q., Buxton, C. D., Carpenter, K. E. (2014): Sarpa salpa. - In the IUCN red list of threatened species. Version 2015.2. Available at http://www.iucnredlist.org.

[38] Sarkar, A., Upadhyay, B. (2011): Influence of photoperiod and temperature on reproduction and gonadal maturation in goldfish: Carassius auratus. - International Journal of Applied Biology and Pharmaceutical Technology 2: 352-358.

[39] Sellami, A., Bruslé, J. (1975): Contribution à l'étude de la sexualité de la saupe Boops salpa Linnaeus 1758 (téléostéen Sparidae) des côtes de Tunisie. - Vie Milieu 25: 261275.

[40] Van der Walt, B. A., Beckley, L. E. (1997): Age and growth of Sarpa salpa (Pisces: Sparidae) off the east coast of South Africa. - Fisheries Research 31: 241-24.

[41] Van der Walt, B. A., Mann, B. Q. (1998): Aspects of the reproductive biology of Sarpa salpa (Pisces: Sparidae) off the east coast of South Africa. - South African Journal of Zoology 33(4): 241-248.

[42] Verlaque, M. (1985): Note préliminaire sur le comportement alimentaire de Sarpa salpa (L.) (Sparidae) en Méditerranée. - Rapport des réunions de la Commission Internationale pour l'Exploitation Scientifique de la Mer Méditerranée 29: 193-196.

[43] Verlaque, M. (1990): Relation entre Sarpa salpa (Linnaeus, 1758) (Téléostéen, Sparidae) les autres poissons brouteurs et le phytobenthos algal méditérranéen. - Oceanologica Acta 13(3): 373-388.

[44] Wootton, R. J. (1990): Ecology of Teleost Fishes. - Chapman and Hall, London. 